\title{
In vitro characterization of intra-generic inhibition of growth in Salmonella typhimurium
}

\author{
A. BERCHIERI, JR $\dagger$ and P. A. BARRow* \\ AFRC Institute for Animal Health, Houghton Laboratory, Houghton, Huntingdon, Cambridgeshire PE17 2DA, UK
}

(Received 9 January 1991; revised 26 May 1991; accepted 18 June 1991)

\begin{abstract}
The intra-generic inhibition of bacterial growth observed previously in vivo and in vitro with strains of Salmonella, Citrobacter and $E$. coli was studied in vitro using $S$. typhimurium strain F98. There was complete inhibition of multiplication of $S$. typhimurium when it was added to stationary-phase broth cultures of different Salmonella serotypes, but only partial inhibition when added to broth cultures of $E$. coli. The degree of inhibition between different mutants of F98 was affected by the numbers of bacteria of the inhibiting strain, but this was not the only factor, since exponential-phase bacterial cells were less inhibitory than stationary-phase cells. The inhibitory effect was produced at temperatures between $20^{\circ} \mathrm{C}$ and $40{ }^{\circ} \mathrm{C}$. The complete inhibition of growth observed between $\mathrm{F98}$ mutants was abolished by ampicillin, rifampicin and streptomycin, but not by nalidixic acid. Inhibition was also prevented by separating the two cultures by a dialysis membrane. A TnphoA insertion mutant of F98 was produced which did not show inhibition in vitro but was still inhibitory in vivo. It is suggested that this complete inhibition of bacterial multiplication between organisms of the same genus, which is greater than that produced between organisms from different genera, is mediated by a cell surface protein.
\end{abstract}

\section{Introduction}

During a search for strains of non-pathogenic enterobacteria which might inhibit the colonization of the chicken intestine by Salmonella typhimurium (Barrow \& Tucker, 1986), it was discovered that colonization of the alimentary tract of newly-hatched chickens by one Salmonella strain imparted a considerable degree of resistance to colonization by a second strain (Barrow $e t$ $a l ., 1987 b$ ). This phenomenon has recently been explored as a potential method for preventing colonization by food-poisoning Salmonella serotypes, by using precolonization with a Salmonella mutant avirulent for chickens and man (Berchieri \& Barrow, 1990). Similar studies on the use of microbial interference to prevent colonization by pathogenic bacteria have been carried out with a number of different genera including Escherichia coli (Duval-Iflah et al., 1983), Clostridium difficile (Borriello \& Barclay, 1985) and skin staphylococci (Noble \& Willie, 1980; Shinefield et al., 1963). It is possible that the mechanisms of inhibition may be different for each type of organism.

The in vivo inhibition of colonization occurring between Salmonella strains was found to be genus-

† Present address: Faculdade de Ciências Agrarias e VeterinariasUNESP, Universidade Estadual Paulista, Jaboticabal SP, Brazil. specific, not mediated by killed bacteria and not the result of immunity or bacteriophage activity (Barrow $e t$ $a l ., 1987 b$ ). A similar phenomenon was observed in vitro in mixed broth cultures. In this case a $24 \mathrm{~h}$ broth culture of a Salmonella strain completely inhibited the multiplication of a subsequently inoculated Salmonella strain, whereas cultures of other genera allowed some multiplication of the second Salmonella strain. The lower level of inhibition produced by other genera is likely to be the result of mechanisms such as oxygen depletion, as suggested by Wilson et al. (1983). However, the mechanism of complete inhibition of multiplication occurring between Salmonella strains in broth is not understood. Its occurrence between isogenic strains precludes bacteriophage and bacteriocin activity. Oxygen or nutrient depletion are not involved and live bacteria are required (Barrow et al., 1987b). Using strains of $S$. typhimurium, the present study attempts to shed some light on this mechanism and to relate it, if possible, to the regulation of bacterial multiplication as it is expressed in stationary-phase bacterial cultures.

\section{Methods}

Bacterial strains. Salmonella typhimurium F98 is a prototrophic, avian, phage type 14 strain which is highly invasive and virulent for 
chickens (Barrow et al., 1987a) and whose faecal excretion characteristics have been well documented (Smith \& Tucker, 1975, 1980). Other Salmonella strains mentioned in the experimental design were all isolated from poultry or from cases of human food-poisoning. A prototrophic porcine Escherichia coli strain, P4, which did not produce complete growth inhibition against $S$. typhimurium, was used as a control organism where necessary.

For the purposes of differentiating one bacterial strain from another in mixed culture experiments, spontaneous chromosomal mutants resistant to either spectinomycin $\left(\mathrm{Spc}^{r}\right)$, nalidixic acid $\left.(\mathrm{Nal})^{r}\right)$, ampicillin $\left(A p^{r}\right)$, rifampicin $\left(\operatorname{Rif}^{r}\right)$, streptomycin $\left(\mathrm{Sm}^{r}\right)$ or both nalidixic acid and spectinomycin $\left(\mathrm{Nal}^{r} \mathrm{Spc}^{r}\right)$ were isolated as described previously (Smith \& Tucker, 1980). With the exception of the rifampicin-resistant mutant, which was of reduced virulence for chickens, these mutants behaved similarly to the antibiotic-sensitive parent strain in both in vivo colonization and in vitro growth inhibition experiments (P. A. Barrow, unpublished findings). TnphoA insertion mutants of F98 Nalr were produced as described below. Unless otherwise indicated, bacterial strains were maintained on Dorset egg slopes at $4{ }^{\circ} \mathrm{C}$ and were cultured in $10 \mathrm{ml}$ nutrient broth (Oxoid CMl) in a shaking water bath $\left(100\right.$ strokes $\left.\mathrm{min}^{-1}\right)$ at $37^{\circ} \mathrm{C}$ for $24 \mathrm{~h}$. These usually contained between $5 \times 10^{8}$ and $1 \times 10^{9}$ c.f.u. $\mathrm{ml}^{-1}$.

Construction and analysis of TnphoA mutants. Plasmid pRT733 (ori R6K, tra ${ }^{-}, \mathrm{mob}^{+}, \mathrm{Ap}^{+}, \mathrm{Km}^{+}$) containing $\mathrm{TnphoA}$, a transposon probe for proteins exported to the cell surface (Manoil \& Beckwith, 1985), was transferred from E. coli SM10 (Simon et al., 1983) into $S$. typhimurium F98 $\mathrm{Nal}^{\mathrm{r}}$ by conjugation on a plate surface (Bradley et al., 1980) as described by Finlay $e t$ al. (1988). Transconjugants were selected on Lagar containing $25 \mu \mathrm{g}$ sodium nalidixate $\mathrm{ml}^{-1}, 45 \mu \mathrm{g}$ kanamycin sulphate $\mathrm{ml}^{-1}$, and $40 \mu \mathrm{g}$ 5-bromo-4-chloro-3-indolyl phosphate $p$ toluidene salt (BCIP) $\mathrm{ml}^{-1}$. Colonies which were darker blue than the parent strain were checked for ampicillin sensitivity indicating loss of pRT733.

One TnphoA mutant of $\mathrm{F} 98 \mathrm{Nal}^{\mathrm{r}}$ was found to be of interest and was examined, together with $\mathrm{F} 98 \mathrm{Nal}^{r}$, in greater detail. Its biochemical properties were tested using the API 20E and API CHO kits (API systems, Montalieu Vercieu, France). The mutant was tested for auxotrophy by serial culture on M9 minimal medium (Sambrook et al., 1989). Whole cell protein and outer-membrane protein (OMP) preparations were prepared as described previously (Hassan et al., 1991) and PAGE of these preparations was carried out in a standard way (Sambrook et al., 1989). The plasmid content of the two strains was examined by the method of Kado \& Liu (1981).

Southern blot analysis of the mutant and parent were carried out as follows. Bacterial chromosomal DNA was prepared by a modification of the method described by Maskell et al. (1988). The pellet from a $100 \mathrm{ml}$ exponential-phase broth culture was resuspended in $2 \mathrm{ml} 25 \%$ (w/v) sucrose in ice-cold $50 \mathrm{~mm}$-Tris, $1 \mathrm{~mm}$-EDTA, pH 8.0. The cells were lysed slowly for 5 mins with $1 \mathrm{mg}$ lysozyme $\mathrm{ml}^{-1}$ on ice, followed by $500 \mu \mathrm{g}$ proteinase $\mathrm{K} \mathrm{ml}^{-1}, 0.1 \mathrm{M}$-EDTA, pH 8.0 , and $2 \%(\mathrm{w} / \mathrm{v}) \mathrm{N}$ lauroylsarcosine (Sarkosyl), the mixture being left on ice until lysis was complete, followed by overnight incubation at $50^{\circ} \mathrm{C}$. After phenol extraction and ethanol precipitation, the DNA was resuspended in $10 \mathrm{~mm}$-Tris, $1 \mathrm{~mm}$-EDTA, pH 8.0. Restriction analysis, gel electrophoresis, nick translations and Southern blot analysis were carried out as described by Sambrook et al. (1989).

Pho $\mathrm{A}^{+}$fusion products of the two strains were sought with nonreducing PAGE, visualizing phosphatase activity with BCIP as described by Finlay et al. (1988).

Phage typing was carried out by Dr L. Ward at the Central Public Health Laboratory, Colindale, London, using a standard set of phages, and by the authors using 17 lysogenic phages, obtained from different $S$. typhimurium strains and used at the routine test dilution (Guinée \& van Leeuwen, 1978).
Chickens. These were from a specified-pathogen-free Light Sussex flock maintained at this laboratory. Their sex was not determined. Their rearing conditions and diet were as described by Smith \& Tucker (1975).

In vivo and in vitro tests for growth inhibition. The methods used were those of Barrow \& Tucker (1986) and Barrow et al. (1987b). A broth culture $(0.1 \mathrm{ml})$ of the strain tested was inoculated orally into the crop of a group of 10 chickens within $24 \mathrm{~h}$ of hatching, and before they were given access to food. Twenty-four hours later they were inoculated orally with $10^{5}$ organisms of $S$. typhimurium F98 Nal ${ }^{r} \mathrm{Spc}^{r}$ in $0.1 \mathrm{ml}$. Three days later, the chickens were killed and viable counts of the challenge strain were performed on their caecal contents by the method of Miles et al. (1938) using brilliant green agar (Oxoid CM 263) containing nalidixic acid $\left(25 \mu \mathrm{g} \mathrm{ml}^{-1}\right)$ and spectinomycin $\left(30 \mu \mathrm{g} \mathrm{ml}^{-1}\right)$. In vitro inhibition was tested by inoculating a $24 \mathrm{~h}$ broth culture of the strain to be tested with the challenge strain (constant initial concentration in the $24 \mathrm{~h}$ broth culture of $10^{4}$ c.f.u. $\mathrm{ml}^{-1}$ ). This was incubated further at $37^{\circ} \mathrm{C}$ in a water bath with shaking, and viable counts of the challenge strain were made at intervals on MacConkey agar (Oxoid CM7) containing an antibiotic to which the challenge strain, but not the test strain, was resistant. In the case of in vitro inhibition, the inhibitory effect in the challenge strain was expressed as the $\log _{10}$ change in viable count after $24 \mathrm{~h}$ incubation. Degrees of inhibition were compared by Fisher's $t$ test.

\section{Experimental design}

Inhibition of S. typhimurium F98 by Salmonella strains. Five antibiotic sensitive strains of $S$. typhimurium, one of which was F98, and individual strains of $S$. infantis, $S$. heidelberg, $S$. virchow, $S$. hadar and $E$. coli $\mathrm{P} 4$ were tested in vitro against $S$. typhimurium $\mathrm{F} 98 \mathrm{Nal}^{r}$. To ensure that the $\mathrm{Nal}^{r}$ mutation per se did not increase the susceptibility of F98 to the effect produced by other strains, F98 Spc ${ }^{r}$ was tested for inhibition against $\mathrm{F98} \mathrm{Nal}^{r}$ and $\mathrm{F98} \mathrm{Nal}^{r}$ was tested against F98 $\mathrm{Spc}^{\mathrm{r}}$.

The effect of bacterial numbers and culture age on inhibition. The effect of the number of bacteria in a culture on its inhibitory effect was tested with serial dilutions, made in nutrient broth, of a $24 \mathrm{~h}$ broth culture of F98 Spcr. These were inoculated with $10^{4}$ c.f.u. $\mathrm{ml}^{-1} \mathrm{F98} \mathrm{Nal}$ and the growth of this latter strain was measured as described above.

The effect of the age of the broth culture of $\mathrm{F} 98 \mathrm{Spc}^{\mathrm{r}}$ was tested by inoculating $10 \mathrm{ml}$ aliquots of nutrient broth with $10^{3}$ c.f.u. F98 Spcr and culturing these in a shaking water bath for up to $28 \mathrm{~d}$. At intervals, individual cultures were inoculated with $10^{4}$ c.f.u. $\mathrm{ml}^{-1} \mathrm{~F} 98 \mathrm{Nal}$, and the growth of this strain was measured as described above.

Since the inhibitory effect on F98 Nalr in these cultures was affected by bacterial numbers in addition to culture age, a second experiment was performed in which $750 \mathrm{ml}$ prewarmed nutrient broth was inoculated with $10^{4}$ c.f.u. $\mathrm{ml}^{-1} \mathrm{~F} 98 \mathrm{Spc}^{r}$ and incubated in a rotary incubator for $2 \mathrm{~h}$. Preliminary experiments had indicated that the bacteria would be in mid-exponential growth phase at this time. The culture was centrifuged at $10000 \mathrm{~g}$ for $10 \mathrm{mins}$ and the pellet resuspended in $5 \mathrm{ml}$ nutrient broth to provide a viable count of approximately $10^{9}$ c.f.u. $\mathrm{ml}^{-1}$. This was inoculated with $10^{4}$ c.f.u. $\mathrm{ml}^{-1}$ F98 Nalr, and the behaviour of the latter strain was tested as described above.

The effect of temperature on inhibition. The effect of temperature was tested using broth cultures of $\mathbf{F} 98 \mathrm{Spc}^{r}$ which had been incubated at $20^{\circ} \mathrm{C}, 30^{\circ} \mathrm{C}, 37^{\circ} \mathrm{C}$ or $42^{\circ} \mathrm{C}$ in water baths, with shaking, until they had reached the stationary phase $(24 \mathrm{~h}$ in all cases). These, and sterile nutrient broths, were inoculated with $10^{4} \mathrm{c}$.f.u. $\mathrm{ml}^{-1} \mathrm{~F} 98 \mathrm{Nal}^{r}$, and the mixed cultures were reincubated at the same temperatures. Growth of F98 $\mathrm{Nal}^{\mathrm{r}}$ was monitored in the usual way.

The effect of antibiotics on inhibition. The effect of selected antibiotics on inhibition was tested. A preliminary experiment was carried out to 
assess the effects of sodium nalidixate $\left(25 \mu \mathrm{g} \mathrm{ml}^{-1}\right)$, ampicillin $(100 \mu \mathrm{g}$ $\left.\mathrm{ml}^{-1}\right)$, streptomycin $\left(100 \mu \mathrm{g} \mathrm{ml}^{-1}\right)$ or rifampicin $\left(250 \mu \mathrm{g} \mathrm{ml}^{-1}\right)$ on the viable numbers of $24 \mathrm{~h}$ broth cultures of antibiotic-sensitive F98. Viable counts were made on both MacConkey agar and freshly made MacConkey agar containing the appropriate antibiotic, at intervals following addition of the antibiotics to the cultures. This was done to ensure that multiplication of antibiotic-resistant mutants did not hinder the detection of a reduction in the viable count of the antibioticsensitive strain. In a second experiment, $48 \mathrm{~h}$ after the addition of the antibiotics to the cultures of $\mathrm{F} 98,10^{4}$ c.f.u. $\mathrm{ml}^{-1}$ of mutants which were either $\mathrm{Nal}^{r}, \mathrm{Ap}^{r}, \mathrm{Sm}^{\mathrm{r}}$ or $\mathrm{Rif}^{r}$, respectively, were added and their subsequent growth was tested, counting the organisms on MacConkey agar containing the appropriate antibiotic.

Separation of cultures by dialysis membrane. The effect on inhibition of separating the cultures by dialysis membrane was tested by inoculating $5 \mathrm{ml}$ sterile nutrient broth with $10^{4}$ c.f.u. $\mathrm{ml}^{-1} \mathrm{~F} 98 \mathrm{Nal}^{\mathrm{r}}$ and placing this aseptically in dialysis tubing $(5.7 \mathrm{~mm}$ diameter) which was then incubated in $150 \mathrm{ml} 24 \mathrm{~h}$ F98 broth culture. The change in viable numbers of the F98 Nal' culture was assessed over $24 \mathrm{~h}$. Appropriate controls (see Table 3) were included.

Analysis of TnphoA mutants of S. typhimurium F98 Natr. A bank of 200 TnphoA mutants of $\mathrm{F98} \mathrm{Nal}^{\mathrm{r}}$ which were darker blue than the parent strain was screened for in vitro inhibition of F98 Nalr Spcr. Cultures which showed reduced inhibition were also tested in vivo and examined for other detectable changes in the cell surface.

\section{Results}

\section{Inhibition of S. typhimurium F98 by Salmonella strains}

The $\log _{10}$ changes in the viable numbers of $S$. typhimurium F98 Nalr after incubation for $24 \mathrm{~h}$ in a culture of antibiotic-sensitive F98 and in nutrient broth were (mean with standard deviation from nine tests) $+0 \cdot 11 \pm 0 \cdot 19$ and $5 \cdot 20 \pm 0 \cdot 47$, respectively. This difference was statistically significant $(P<0.001)$. F98 Nal ${ }^{r}$ also produced complete inhibition of F98 Spcr. The $E$. coli strain produced the degree of partial inhibition described by other authors (Wilson et al., 1983) and attributed to factors such as oxygen depletion $\left(\log _{10}\right.$ change of $+3 \cdot 1 \pm 0 \cdot 88$, results of four tests). This change was significantly different from that found in sterile nutrient broth and from that produced by F98 $\mathrm{Spc}^{\mathrm{r}}$ $(P<0.001)$. The changes in the viable numbers of F98 $\mathrm{Nal}^{\mathrm{r}}$ produced by incubation with four other $S$. typhimurium strains and individual strains of $S$. infantis, $S$. heidelberg, $S$. virchow and $S$. hadar were (results from three tests) $\log _{10}+0.08 \pm 0.05,-0.10 \pm 0.07$, $-0.10 \pm 0.09, \quad-0.13 \pm 0.08, \quad+0.15 \pm 0.07$, $+0.04 \pm 0.19,-0.08 \pm 0.16$ and $+0.03 \pm 0.17$.

\section{The effect of bacterial numbers and culture age on inhibition}

The inhibition of growth of $\mathrm{F} 98 \mathrm{Nal}^{\mathrm{r}}$ by diluted cultures of F98 Spcr is shown in Fig. 1 which represents the mean

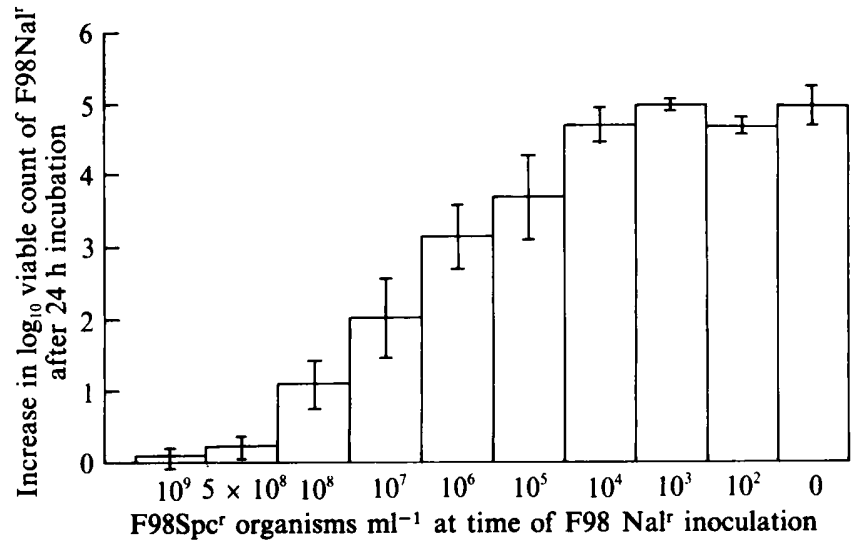

Fig. 1. Inhibition of $S$. typhimurium $\mathrm{F} 98 \mathrm{Nal}^{\mathrm{r}}$ by dilutions of $24 \mathrm{~h}$ broth cultures of F98 Spcr.

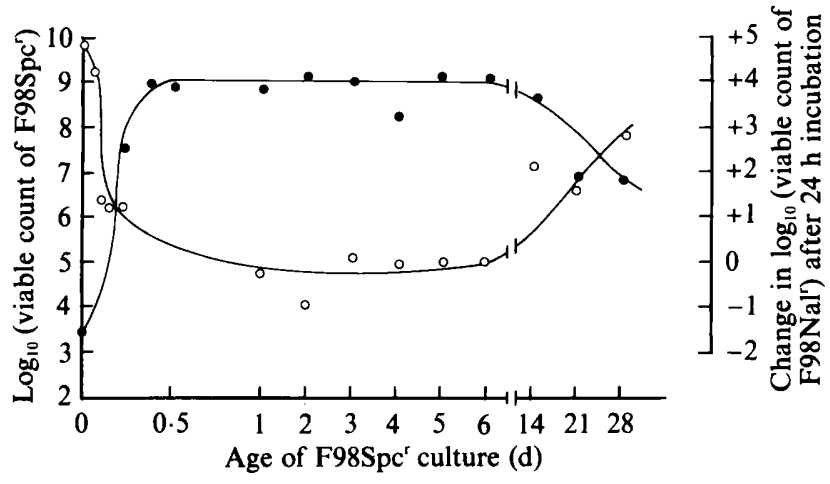

Fig. 2. Inhibition of $S$. typhimurium F98 $\mathrm{Nal}^{\mathrm{r}}$ by broth cultures of $\mathrm{F98}$ $\mathrm{Spc}^{\mathrm{r}}$ sampled at various times during the growth cycle. (O) $\log _{10}$ (viable numbers $\mathrm{ml}^{-1}$ ) of $\mathrm{F98} \mathrm{Spc}^{\mathrm{r}}$ at times after inoculation of nutrient broth. (O) Increase after $24 \mathrm{~h}$ in $\log _{10}$ (viable numbers $\mathrm{ml}^{-1}$ ) of F98 $\mathrm{Nal}$ after inoculation into aliquots of $\mathrm{F} 98 \mathrm{Spc}^{\mathrm{r}}$.

of results from three experiments. The degree of suppression of growth of F98 Nalr decreased as the numbers of $\mathrm{F} 98 \mathrm{Spc}^{\mathrm{r}}$ decreased until at a concentration of approximately $10^{4}$ c.f.u. of $\mathrm{F} 98 \mathrm{Spc}^{r} \mathrm{ml}^{-1}$ no detectable inhibition occurred.

The $\log _{10}$ increases over $24 \mathrm{~h}$ in the numbers of F98 $\mathrm{Nal}^{\mathrm{r}}$ after incubation in cultures of $\mathrm{F} 98 \mathrm{Spc}^{\mathrm{r}}$ that were taken at different stages of the growth curve are shown in Fig. 2, along with the viable numbers of F98 Spcr. There was an inverse correlation between inhibition and the numbers of $\mathrm{F} 98 \mathrm{Spc}^{\mathrm{r}}$ organisms present in the cultures $(n=27$ from two experiments, $r=-0.961)$. Thus inhibition seemed to commence when the viable numbers of F98 $\mathrm{Spc}^{\mathrm{r}}$ had reached $10^{4}-10^{5}$ c.f.u. $\mathrm{ml}^{-1}$ although it did not reach a maximum until F98 $\mathrm{Spc}^{\mathrm{r}}$ was well into the stationary phase; it began to decrease in the phase of decline, from $14 \mathrm{~d}$ onwards.

To test whether the reduced inhibition seen during the 
exponential phase was due solely to low bacterial numbers, organisms of F98 $\mathrm{Spc}^{r}$ harvested at midexponential-phase were centrifuged and resuspended at high density $\left(\log _{10} 8.94 \mathrm{ml}^{-1}\right)$. The $\log _{10}$ increase in viable numbers over $24 \mathrm{~h}$ of $\mathrm{F} 98 \mathrm{Nal}^{\mathrm{r}}$ inoculated into this culture was 1.3 (mean of two tests), indicating that high numbers alone are not sufficient to produce complete inhibition and that cells produced different amounts of the inhibitory principle at different stages of growth. Centrifugation and resuspension in fresh broth had no effect on the inhibitory activity of a stationary phase culture (results not shown).

\section{The effect of temperature on inhibition}

The inhibition of $\mathrm{F} 98 \mathrm{Nal}^{\mathrm{r}}$ by cultures of $\mathrm{F98} \mathrm{Spc}^{\mathrm{r}}$ was studied at different temperatures, all of which allowed F98 Spcr to reach stationary phase after $24 \mathrm{~h}$ incubation in broth. The $\log _{10}$ changes in the numbers of $\mathrm{F} 98 \mathrm{Nal}^{\mathrm{r}}$ $\mathrm{ml}^{-1}$ after $24 \mathrm{~h}$ incubation in mixed culture at $20^{\circ} \mathrm{C}$, $30^{\circ} \mathrm{C}, 37^{\circ} \mathrm{C}$ and $42^{\circ} \mathrm{C}$ were $+0.19 \pm 0.06,0.10 \pm 0.52$, $0 \cdot 23 \pm 0 \cdot 18$, and $0 \cdot 20 \pm 0 \cdot 34$, respectively. The $\log _{10}$ increases in $\mathrm{F} 98 \mathrm{Nal}^{\mathrm{r}}$ numbers $\mathrm{ml}^{-}$in sterile nutrient broth at these temperatures were $4.53 \pm 0.18$, $5.04 \pm 0.40,4.96 \pm 0.45$ and $4.80 \pm 0.27$ at all four temperatures. When the $\log _{10}$ changes in the viable count of the challenge strain after incubation in the F98 $\mathrm{Spc}^{\mathrm{r}}$ cultures were compared with those made in nutrient broth, $P$ was $<0.01$ for all four temperatures.

\section{The effect of antibiotics on inhibition}

The minimum inhibitory concentration (MIC) values of ampicillin, streptomycin, nalidixic acid and rifampicin

\section{Table 1. Effect of antibiotics on S. typhimurium $F 98$}

Antibiotics were added to $24 \mathrm{~h}$ broth cultures, which were sampled as indicated, and counted after plating. All determinations were made on MacConkey agar, with $(+)$ or without $(-)$ the same antibiotic used in the broth culture. Results are means of two experiments.

\begin{tabular}{|c|c|c|c|c|c|c|c|c|}
\hline \multirow{3}{*}{$\begin{array}{l}\text { Time } \\
\text { after } \\
\text { addition } \\
\text { (h) }\end{array}$} & \multicolumn{8}{|c|}{$\begin{array}{c}\log _{10} \text { (viable numbers } \mathrm{ml}^{-1} \text { ) } S . \text { typhimurium } \mathrm{F98} \\
\text { after addition of: }\end{array}$} \\
\hline & \multicolumn{2}{|c|}{$\begin{array}{c}\text { Nalidixic } \\
\text { acid } \\
\left(25 \mu \mathrm{g} \mathrm{ml}^{-1}\right)\end{array}$} & \multicolumn{2}{|c|}{$\begin{array}{l}\text { Ampicillin } \\
\left(100 \mu \mathrm{g} \mathrm{ml}^{-1}\right)\end{array}$} & \multicolumn{2}{|c|}{$\begin{array}{l}\text { Rifampicin } \\
\left(250 \mu \mathrm{g} \mathrm{ml}^{-1}\right)\end{array}$} & \multicolumn{2}{|c|}{$\begin{array}{l}\text { Streptomycin } \\
\left(100 \mu \mathrm{g} \mathrm{ml}^{-1}\right)\end{array}$} \\
\hline & + & - & + & - & + & - & + & - \\
\hline 0 & $<1.0$ & 8.8 & $<1.0$ & 8.9 & $<1.0$ & $8 \cdot 5$ & $<1.0$ & 8.7 \\
\hline 2 & $<1 \cdot 0$ & 8.8 & $<1.0$ & $8 \cdot 3$ & $<1.0$ & $7 \cdot 9$ & $<1.0$ & $8 \cdot 6$ \\
\hline 4 & $<1.0$ & 8.8 & $<1.0$ & $7 \cdot 8$ & $<1.0$ & $9 \cdot 2$ & $<1.0$ & $8 \cdot 2$ \\
\hline 6 & $<1.0$ & 8.8 & $<1.0$ & $7 \cdot 9$ & 1.0 & $9 \cdot 2$ & $<1.0$ & $8 \cdot 2$ \\
\hline 24 & $<1.0$ & 8.8 & $<1.0$ & $5 \cdot 5$ & $4 \cdot 6$ & 8.4 & $<1.0$ & $7 \cdot 8$ \\
\hline 48 & $<1.0$ & 8.9 & $<1.0$ & $4 \cdot 3$ & 8.5 & $7 \cdot 7$ & $<1.0$ & $7 \cdot 5$ \\
\hline
\end{tabular}

Table 2. Inhibition of growth of antibiotic resistant mutants of Salmonella typhimurium F98 by broth cultures of the antibiotic-sensitive parent strain in the presence of antibiotics

Antibiotics were added to $24 \mathrm{~h}$ broth cultures of $S$. typhimurium F98, followed $48 \mathrm{~h}$ later by $10^{4}$ c.f.u. $\mathrm{ml}^{-1}$ antibiotic-resistant mutants. Results are means from two experiments.

\begin{tabular}{llc}
\hline \multicolumn{1}{c}{ Antibiotic used } & $\begin{array}{c}\text { Mutant } \\
\text { resistant to: }\end{array}$ & $\begin{array}{c}\text { Log }_{10} \text { change in } \\
\text { viable count } \\
\text { ml }\end{array}$ \\
mutant of $\mathrm{F98}$ \\
Ampicillin $\left(100 \mu \mathrm{g} \mathrm{ml}^{-1}\right)$ & Ampicillin & 3.8 \\
None & Ampicillin & $0 \cdot 2$ \\
Nalidixic acid $\left(25 \mu \mathrm{g} \mathrm{ml}^{-1}\right)$ & Nalidixic acid & 0.4 \\
None & Nalidixic acid & -0.2 \\
Rifampicin $\left(250 \mu \mathrm{g} \mathrm{ml}^{-1}\right)$ & Rifampicin & $4 \cdot 2$ \\
None & Rifampicin & 0.3 \\
Streptomycin $\left(100 \mu \mathrm{g} \mathrm{ml}^{-1}\right)$ & Streptomycin & 3.4 \\
None & Streptomycin & 0.1 \\
\hline \hline
\end{tabular}

for F98 were $0.49,7.8,1.95$ and $3.9 \mu \mathrm{g} \mathrm{ml}^{-1}$ respectively. The MIC values for the F98 strains resistant to these individual antibodies were $250,500,1000$ and $250 \mu \mathrm{g}$ $\mathrm{ml}^{-1}$, respectively. The results of the initial experiment, in which the effect of selected antibiotics on the viable numbers of F98 in $24 \mathrm{~h}$ broth cultures was studied are shown in Table 1. Only ampicillin had a marked effect on F98, although this was not apparent for at least $6 \mathrm{~h}$. Streptomycin produced a small reduction in numbers over $48 \mathrm{~h}$ and rifampicin and nalidixic acid produced no detectable effect at all. Antibiotic-resistant organisms were only detected following rifampicin treatment. These appeared at $6 \mathrm{~h}$ and increased rapidly in numbers up to the end of the experiment.

The effect of the same antibiotics on the inhibition by F98 of appropriate antibiotic-resistant mutants of F98 is shown in Table 2. Inhibition of F98 Nal' ${ }^{\mathrm{r}}$ occurred in the presence of nalidixic acid. Complete inhibition of growth of F98 Apr, F98 Rif ${ }^{r}$ and F98 $\mathrm{Sm}^{\mathrm{r}}$ was, however, abolished by the presence of ampicillin, rifampicin and streptomycin, respectively. Protein synthesis and an intact envelope structure therefore appear to be essential for complete inhibition of multiplication to occur.

\section{Separation of F98 cultures by dialysis membrane}

When small numbers of organisms of the challenge strain F98 $\mathrm{Nal}^{\mathrm{r}}$ were separated from an overnight culture of F98 by a dialysis membrane a reduced inhibition of multiplication of F98 Nalr was obtained, similar to that observed when cells of F98 Nalr were introduced into a culture of $E$. coli (Table 3). Appropriate controls of single cultures inside or outside the dialysis tubing or of mixed Salmonella cultures outside the tubing behaved as expected. Reduced inhibition less than that produced by 
Table 3. Effect on growth inhibition of Salmonella typhimurium F98 Nal of separating the two strains with a dialysis membrane

\begin{tabular}{|c|c|c|}
\hline $\begin{array}{c}\text { Strain outside } \\
\text { dialysis membrane }\end{array}$ & $\begin{array}{c}\text { Strain inside } \\
\text { dialysis membrane }\end{array}$ & $\begin{array}{l}\log _{10} \text { increase in } \\
\text { viable count of F98 } \\
\text { Nal' over } 24 \mathrm{~h} \|\end{array}$ \\
\hline None* & F98 $\mathrm{Nal}^{\mathrm{r}}$ & $5.48 \pm 0.39^{a}$ \\
\hline F98 $\mathrm{Nal}^{\top} \dagger$ & None & $5 \cdot 38 \pm 0 \cdot 27^{b}$ \\
\hline F98 sens/F98 Nal' & None & $0 \cdot 30 \pm 0 \cdot 17^{c}$ \\
\hline F98 sens§ & F98 $\mathrm{Nal}^{\mathrm{r}}$ & $3.21 \pm 0.86^{d}$ \\
\hline E. coli $\mathrm{P} 4 / \mathrm{F} 98 \mathrm{Nal}^{\prime} \ddagger$ & None & $3.50 \pm 0.65^{e}$ \\
\hline
\end{tabular}

* $10^{4}$ c.f.u. $\mathrm{ml}^{-1} \mathrm{~F} 98 \mathrm{Nal}^{\mathrm{r}}$ added aseptically to dialysis tubing placed in $150 \mathrm{ml}$ sterile nutrient broth.

$\dagger 10^{4}$ c.f.u. $\mathrm{ml}^{-1} \mathrm{~F} 98 \mathrm{Nal}^{\mathrm{r}}$ added directly to $150 \mathrm{ml}$ sterile nutrient broth.

$\ddagger 10^{4}$ c.f.u. $\mathrm{ml}^{-1} \mathrm{~F} 98 \mathrm{Nal}^{\mathrm{r}}$ added directly to $150 \mathrm{ml} 24 \mathrm{~h}$ nutrient broth culture of either antibiotic-sensitive parent strain F98 or Escherichia coli $\mathbf{P 4}$.

$\S 10^{4}$ c.f.u. $\mathrm{ml}^{-1} \mathrm{F98} \mathrm{Nal}{ }^{r}$ added aseptically to dialysis tubing placed in $150 \mathrm{ml} 24 \mathrm{~h}$ nutrient broth culture of antibiotic-sensitive parent strain F98.

\|Statistical significance of comparisons: $a$ vs $d, P<0.001 ; a$ vs $c$, $P=0.002 ; a$ vs $e, P=<0.001 ; d$ vs $e, P=0.351$.

the $E$. coli strain was not expected because other factors such as oxygen depletion (Wilson et al., 1983) would still be active.

\section{Inhibition by and analysis of a Tnpho A mutant of F98 Nalr}

Of 200 colonies of $\mathrm{F} 98 \mathrm{Nal}^{\mathrm{r}}$ which were darker blue than the parent strain, only one produced a reduced inhibition of multiplication of F98 Nalr $\mathrm{Spc}^{r}$, similar to that produced by $E$. coli. The $\log _{10}$ increases in numbers of F98 $\mathrm{Nal}^{\mathrm{r}} \mathrm{Spc}^{\mathrm{r}}$ over $24 \mathrm{~h}$ in cultures of $\mathrm{F} 98 \mathrm{Nal}^{\mathrm{r}}$, E. coli $\mathrm{P} 4$, the Tnpho $A$ mutant (designated AB145) and in sterile nutrient broth, were $0 \cdot 27 \pm 0 \cdot 29,3 \cdot 4 \pm 0 \cdot 78,3 \cdot 33 \pm 1 \cdot 11$ and $4.93 \pm 0 \cdot 12$, respectively. The statistical significance ( $P$ values) in the differences in the changes in viable count of $\mathrm{F} 98 \mathrm{Nal}^{r} \mathrm{Spc}^{\mathrm{r}}$ when incubated with $\mathrm{AB} 145$ and when incubated with $E$. coli $\mathrm{P} 4, \mathrm{~F} 98 \mathrm{Nal}^{\mathrm{r}}$ and with nutrient broth, were $0.46,0.001$ and $0 \cdot 117$. The value for the comparison of the change in viable count of F98 Nalr $\mathrm{Spc}^{\mathrm{r}}$ produced by incubation in the culture of $E$. coli $\mathrm{P} 4$ and in nutrient broth was $P=0.065$.

Southern analysis of chromosome DNA from F98 Nalr and from the mutant AB145, when digested with EcoRV and probed with radiolabelled pRT733 (Fig. 3), indicated that the insertion had occurred in a $1.4 \mathrm{~kb}$ fragment since TnphoA is $7.6 \mathrm{~kb}$ in size (Finlay et al., 1988). When examined for plasmid content, both strains possessed a single $85 \mathrm{kbp}$ plasmid. No phoA fusion products were detected in the mutant. There was no apparent difference in the protein profiles obtained by

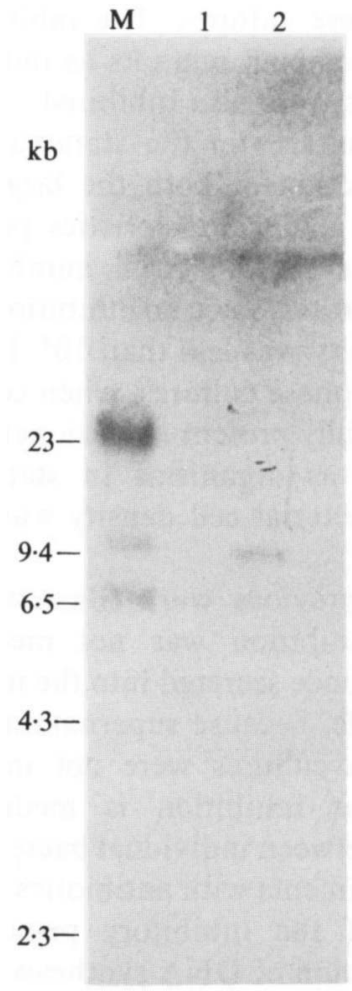

Fig. 3. Autoradiograph of Southern blot from a gel of separated chromosomal fragments from $S$. typhimurium F98 Nalr and TnphoA insertion mutant $\mathrm{AB} 145$, digested with EcoRV and probed with ${ }^{32} \mathrm{P}$ labelled pRT733. Lane 1, F98 Nal'; lane 2, F98 Nal' mutant AB145. The positions of molecular mass markers $(M)$ are indicated on the left. The marker is a HindIII digest of $\lambda$ DNA.

PAGE of whole-cell soluble and outer-membrane proteins using a silver stain (results not presented); neither was any difference detected between the two strains in their biochemical activity, pattern of carbohydrate fermentation or sensitivity to a number of bacteriophages. Both strains were prototrophic.

When tested in vivo in newly hatched chicks, strain $\mathrm{AB} 145$ was as inhibitory as the parent strain. The $\log _{10}$ viable counts of F98 Nalr ${ }^{r} \mathrm{pc}^{\mathrm{r}}$ in the caecal contents of chicks administered $\mathrm{F} 98 \mathrm{Nal}^{\mathrm{r}}, \mathrm{AB} 145$ or nothing within $24 \mathrm{~h}$ of hatching, followed by F98 Nal${ }^{r} \mathrm{Spc}^{\mathrm{r}} 24 \mathrm{~h}$ later were (median with range in parenthesis) $<2.0(<2.0$ $3 \cdot 3),<2 \cdot 0(<2 \cdot 0-4 \cdot 2)$ and $7 \cdot 4(6 \cdot 2-8 \cdot 4)$. Strain AB145, reisolated from chickens at the end of the experiment, was still resistant to kanamycin.

\section{Discussion}

As found previously (Barrow et al., 1987), stationary phase cutures of $S$. typhimurium and other Salmonella serotypes, but not $E$. coli, inhibited the multiplication of small numbers of $S$. typhimurium organisms when 
inoculated into these cultures. The inhibition was not related to the use of $\mathrm{Nal}^{\mathrm{r}}$ mutants as indicator strains, since $\mathrm{Spc}^{r}$ mutants were also inhibited.

Inhibition by cultures in the stationary phase may have been a reflection of both the large numbers of organisms present and characteristics peculiar to this stage of the life cycle. Bacterial numbers, or rather density, were important, since no inhibition was detected when the cell density was less than $10^{4}-10^{5}$ c.f.u. $\mathrm{ml}^{-1}$. Early exponential-phase cultures, when concentrated to the numbers normally present in stationary phase, were not as inhibitory as organisms in stationary phase, suggesting that bacterial cell density was not the only important factor.

The results of previous work (Barrow et al., 1987) suggested that inhibition was not mediated by an extracellular substance secreted into the medium, unless this was very labile, because supernatants obtained by centrifuging broth cultures were not inhibitory. One alternative is that inhibition is mediated through physical contact between individual bacterial cells in the culture. The experiments with antibiotics suggested that the production of the inhibitory principle was not affected by prevention of DNA synthesis with nalidixic acid. However, ampicillin, which prevents cross-link formation in the construction of peptidoglycan by the bacterial cell, and thus affects the integrity of the bacterial envelope, did abolish inhibition. Streptomycin and rifampicin, both affecting protein synthesis, also eliminated inhibition. Rifampicin specifically affects RNA polymerase which also plays an integral role in the initiation of DNA replication (Meyenburg \& Hansen, 1989). The hypothesis is thus that intra-generic inhibition of bacterial multiplication is mediated by a bacterial surface protein, and that some form of physical bacterium-bacterium interaction is involved. The latter is also suggested by the lack of inhibition when the two strains were separated by dialysis tubing. Although this does not preclude mediation via a high-molecular-mass molecule released into the broth culture, it seems unlikely that the bacterial cells would synthesise a large, labile molecule continuously and release it into the environment for this purpose.

The TnphoA insertion mutation can be used to identify proteins which are transported to the bacterial cell surface (Manoil \& Beckwith, 1985) and has been used recently to study surface proteins involved in the invasion of eukaryotic cells by $S$. cholerae-suis (Finlay et al., 1988). In the present study one mutant of $S$. typhimurium $\mathrm{F} 98 \mathrm{Nal}^{\mathrm{r}}$ did not produce in vitro inhibition of multiplication, suggesting that a surface protein may indeed be involved. However, no differences were detectable between the protein profiles of the parent and the mutant using one-dimensional gels. Neither was alkaline phosphatase activity detectable in surface preparations made from the mutant. Such mutants were also described by Finlay et al. (1988). One explanation for this anomaly is that the insertion of TnphoA actually occurred in the signal sequence of the target gene, such that export of alkaline phosphatase to the cell exterior did not occur, although this would not easily explain the initial isolation of mutant $\mathrm{AB} 145$ as a colony which was darker in colour than the parent strain.

Although intra-generic inhibition of bacterial multiplication occurs between Salmonella strains in vivo and in vitro, Barrow et al. (1987b) did suggest that the mechanisms involved might be different. The fact that AB145 did not produce this inhibition in vitro but did so in vivo suggests that this might be the case. Additional factors present in vivo, such as differences in intestinal colonization ability, may be involved which are not expressed in vitro and vice versa.

How signals received at the bacterial surface might affect replication is unclear, but they could be accommodated into either of the two models for replication control, namely the dilution of an inhibitor or the accumulation of an initiator (Meyenburg \& Hansen, 1989). These authors suggest that a number of factors interact with the origin of replication, ori $C$, and that this and replication complexes, the replisome, can be isolated in association with bacterial membranes (Jacq et al., 1983; Kusano et al., 1984; Wolf-Watz, 1984), although this may conceivably be an artifact of preparation. The fact that the inhibition of bacterial multiplication is related to replication initiation is supported by the inhibitory effect of rifampicin on both.

Further progress in elucidating the mechanisms of in vitro and in vivo expression of genus-specific inhibition of bacterial multiplication might be made by the examination of more TnphoA mutants. The purification of the inhibitory principle would also assist in this and would allow its assessment in vitro and in vivo.

The authors wish to thank Miss M. A. Lovell, Mr B. Wells and Miss V. Peters for assistance in a number of ways. A. B. wishes to thank CNPQ and FUNDUNESP, SP, Brazil for financial support.

\section{References}

BARROW, P. A. \& TUCKER, J. F. (1986). Inhibition of colonization of the chicken alimentary tract with Salmonella typhimurium by pretreatment with strains of Escherichia coli. Journal of Hygiene 96, 161169.

Barrow, P. A., Huggins, M. B., Lovell, M. A. \& Simpson, J. M. $(1987 a)$. Observations on the pathogenesis of experimental Salmonella typhimurium infections in chickens. Research in Veterinary Science 42, 194-199.

Barkow, P. A., TUCKer, J. F. \& Simpson, J. M. (1987b). Inhibition of colonization of the chicken alimentary tract with Salmonella typhimurium by gram-negative facultatively anaerobic bacteria. Epidemiology and Infection 98, 311-322. 
Berchieri, A., JR \& Barrow, P. A. (1990). Further studies on the inhibition of colonization of the chicken alimentary tract with Salmonella typhimurium by pre-colonization with an avirulent mutant. Epidemiology and Infection 104, 427-441.

Borriello, S. P. \& Barclay, F. E. (1985). Protection of hamsters against Clostridium difficile ileocaecitis by prior colonization with non-pathogenic strains. Journal of Medical Microbiology 19, 339-350.

Bradley, D. E., TAYLOR, D. E. \& COMEN, D. R. (1980). Specification of surface mating systems among conjugative drug resistance plasmids in Escherichia coli K12. Journal of Bacteriology 143, 14661470.

Duval-Iflah, Y., Chappuis, J. P., Ducluzeau, R. \& Raibaud, P. (1983). Intra-specific interactions between Escherichia coli in human newborns and in gnotobiotic mice and piglets. Progress in Food and Nutrition Science 7, 107-116.

Finlay, B. B., Starnbach, M. N., Francis, C. L., Stocker, B. A. D., Chatfield, S., Dougan, G. \& Falkow, S. (1988). Identification and characterisation of Tnpho A mutants of Salmonella that are unable to pass through a polarized MDCK epithelial cell monolayer. Molecular Microbiology 2, 757-766.

Guinée, P. A. M. \& VAN Leeuwen, W. J. (1978). Phage typing of Salmonella. Methods in Microbiology 11, 157-191.

Hassan, J. O., MocketT, A. P. A., CATty, D. \& Barrow, P. A. (1991). Infection and reinfection of chickens with Salmonella typhimurium; bacteriology and immune responses. Avian Diseases (in the Press).

JacQ, A., Kohiyama, M., Lother, H. \& Messer, W. (1983). Recognition sites for a membrane-derived DNA binding protein preparation in the E. coli replication origin. Molecular and General Genetics 191, 460-465.

KaDO, C. I. \& LIU, S. T. (1981). Rapid procedure for detection and isolation of large and small plasmids. Journal of Bacteriology 145, 1365-1373.

Kusano, T., Steinmetz, D., Hendrickson, W. G., Murchie, J., KING, M., Benson, A. \& Schaechter, M. (1984). Direct evidence for specific binding of the replicative origin of the $E$. coli chromosome to the membrane. Journal of Bacteriology 158, 313-316.

MaNoIL, C. \& BeCKWITH, J. (1985). TnphoA: a transposon probe for protein export signals. Proceedings of the National Academy of Sciences of the United States of America 82, 8129-8133.
Maskell, D. J., Morrissey, P. \& Dougan, G. (1988). Cloning and nucleotide sequence of the aro $A$ gene of Bordetella pertussis. Journal of Bacteriology 170, 2467-2471.

MEYENBURG, K. \& HANSEN, F. G. (1989). Regulation of chromosome replication. In Escherichia coli and Salmonella typhimurium: Cellular and Molecular Biology, 2nd edn, pp. 1555-1577. Edited by F. C. Neidhardt, J. L. Ingraham, K. B. Low, B. Magasanik, M. Schaechter and H. E. Umbarger. Washington DC: American Society for Microbiology.

Miles, A. A., MisRA, S. S. \& IRwin, J. O. (1938). The estimation of the bactericidal power of the blood. Journal of Hygiene 38, 732-749.

NoBle, W. C. \& WILLIE, J. A. (1980). Interactions between antibiotic producing and non-producing staphylococci in skin surface and subsurface models. British Journal of Experimental Pathology 61, 339343.

Sambrook, J., Fritsch, E. F. \& Maniatis, T. (1989). Molecular Cloning: a Laboratory Manual, 2nd edn, vols. 1-3. Cold Spring Harbor NY: Cold Spring Harbor Laboratory.

Shinefield, M. R., RibBle, J. C., Boris, M. \& Eichenwald, H. F. (1963). Bacterial interference: its effect on nursery acquired infections with Staphylococcus aureus I, II, III, IV. American Journal of Diseases of Childhood 105, 646-682.

Simon, R., Preifer, U. \& PuHLer, A. (1983). A broad host range mobilization system for in vivo genetic engineering: transposon mutagenesis in Gram negative bacteria. Bio/Technology 1, 784-789.

SMITH, H. W. \& TUCKER, T. F. (1975). The effect of antibiotic therapy on the faecal excretion of Salmonella typhimurium by experimentally infected chickens. Journal of Hygiene 75, 275-292.

SMITH, H. W. \& TUCKER, J. F. (1980). The virulence of Salmonella strains for chickens; their excretion by infected chickens. Journal of Hygiene 84, 479-488.

Wilson, G. S., Miles, A. A. \& Parker, M. T. (1983). Topley and Wilson's Principles of Bacteriology, Virology and Immunity, 7th edn. London: Edward Arnold.

Wolf-WatZ, H. W. (1984). Affinity of two different regions of the chromosome to the outer membrane of E. coli. Journal of Bacteriology 157, 968-970. 